\title{
Bureaucracy, Democracy, and Public Administration: Editor's Brief Introduction to the Symposium
}

\author{
Ali Farazmand
}

Published online: 9 September 2010

(C) Springer Science+Business Media, LLC 2010

The twin subjects of bureaucracy and democracy have captured a heightened attention of people all over the world, especially scholars of political science, public administration, and sociology, for the last 30 years or so. Although a long debated issue raised by philosophers and political thinkers for centuries, if not millennia, the contemporary debate on the relationship between bureaucracy and democracy began with concentrated and prolific scholarship since after World War II. Those arguing for a stronger democracy with a weak bureaucracy controlled by democratic processes and elected officials have endured in their crusade against unelected administrative officials performing government functions on professional and mainly meritorious bases. Their bureaucracy-bashing of the last few decades has reached its commanding height. They have prevailed for the most part in at least partially dismantling the professional administrative state, privatizing and outsourcing the public sector functions of governments to private sector contractors, mostly large corporations.

Corporate globalization of the world has, by the virtue of the sheer size and politicoeconomic power global corporations possess and exercise, has transformed the role of governments into mere instruments of providing security and safe heaven for corporations to reign in freely and without constraints. Obviously, such a transformation has had and will continue to have serious impacts on and consequences for public governance, administration, and bureaucracy that serves both processes. Critics of globalization and of the conservative right approach to governance and administration see this transformation a danger to environment, quality of public life, service delivery, and above all to accountability in public governance and administration.

\footnotetext{
A. Farazmand $(\triangle)$

School of Public Administration, Florida Altantic University, 111 East Las Olas Boulevard, Fort Lauderdale, FL 33301, USA

e-mail: afarazma@fau.edu
} 
These critics point to the deficiencies of democracy and stress the need for more professionalized, meritorious, and competent administrative institutions and processes that can correct the flaws of political processes, provide sound administrative decisions and services to the public, carry out the functions and responsibilities of governments, and deliver services with fairness and standardized administrative behaviors. This is what the bureaucracy as an institution of modern governance and government does. Whether viewed as a machinery of modern government, a system of administrative organization, or an organizational instrument of political control and domination, bureaucracy has proven to be one of the most enduring institutions that has survived several millennia-it has survived political changes and revolutions, and has prevailed since the ancient time.

The argument for bureaucracy is simple: it stands for stability and order, impartiality and fairness, standard administrative behavior, and it is always there, whereas political processes change, political masters come and go, and mistakes are made in political changes and revolutions. Engaging citizens in the administrative processes of the bureaucracy is a recent development and is welcomed by both scholars and administrators in the bureaucratic institutions; it is an important step in democratizing the bureaucracy and public governance. It also provides an avenue for citizens to see and appreciate what and how public administrators do. Making progress toward this end, 'representative bureaucracy' has become one way to democratize the bureaucracy, while other ways are being tried out, such as direct citizen involvement in community administration affairs.

The articles published in this symposium address some of the central issues surrounding the relationship between bureaucracy and democracy. They cover a broad scope of knowledge on the subject, plus cases and countries going through transformations from one level to the other. Guy Peters offers a succinct analysis of bureaucracy and democracy relationship in light of the recent changes in both the political/democratic and administrative fields. His argument that bureaucracy is needed and supplements democracy is a powerful one. Next, Robert Durant's article covers similar argument via specific institutional cases in the United States, particularly, with reference to the greening of the military. The third article by Ali Farazmand offers a theoretical analysis and covers a wide range of issues, concepts, and analysis on bureaucracy and democracy and their meanings, bureaucratic and democratic politics, and the relationship between democracy and bureaucracy, arguing that bureaucracy has survived millennia of political changes and masters and that it is a hypocrisy to talk of a functioning democracy without a sound bureaucracy. King Chow offers an extensive and thorough analysis of the bureaucracy and administrative system in China, with implications for political and administrative transformations, and for democratic processes in public governance and administration.

The fifth article by Demetrios Argyriades offers an analysis of bureaucracy and debureaucratization, with a focus on the literature and on the last few decades of the crusade against bureaucracy, pointing out the flows of the reinventing government reform movement and the need for appreciating the merits of a professional bureaucracy to carry out modern public administration and governance functions. The last article by Bidhya Bowornwathana and Ora-orn Poocharoen discuss 
administrative reform as a political issue in the process of bureaucratic politics; their discussion highlights the importance of bureaucracy in the policy process and administrative behavior to serve democracy. Together, we hope these special symposium articles offer useful information and contributes to the continuing debate over bureaucracy and democracy relationship in modern governance and public administration.

\title{
Ali Farazmand \\ Editor in Chief
}

\begin{abstract}
Ali Farazmand is Professor of Public Administration at Florida Atlantic University, author of over 115 articles and book chapters, as well as author and editor of 20 books and handbooks, and the Founding Editor in Chief of Public Organization Review: a Global Journal. His articles have appeared in Public Administration Review, Administration and Society, International Journal of PA, International Review of Administrative Sciences, and Money and Management, among others. His recent books include Bureaucracy and Administration; Globalization, Governance, and Public Administration; and Sound Governance. His forthcoming books are Public Administration in a Globalized World (a textbook), American Administrative State: Institutionalization and Globalization, Modern Organizations: Theory and Behavior, and The Age of Globalization: Governance, Administration, and Bureaucracy.
\end{abstract}

